\title{
Rancangan dan Tanggap Darurat terhadap Bahaya Kebakaran di Rumah Sakit Bhakti Dharma Husada Surabaya
}

\author{
Rizky Rahadian Wicaksono ${ }^{1}$, Gading Wilda Aniriani ${ }^{1}$
}

Email: rahadian.rizky85@gmail.com

1) Dosen S1 Program Studi Ilmu Lingkungan Fakultas Teknik Universitas Islam Lamongan

\begin{abstract}
ABSTRAK
Rumah Sakit adalah salah satu tempat yang tidak terlepas dari bahaya kebakaran, untuk mengurangi dan mencegah kerugian materil dan korban jiwa maka diperlukan suatu rancangan dan tanggap darurat terhadap bahaya kebakaran. Tujuan dari penelitian ini adalah untuk memperoleh informasi gambaran pelaksanaan rancangan dan tanggap darurat terhadap bahaya kebakaran di Rumah Sakit Bhakti Dharma Husada Surabaya. Penelitian ini adalah penelitian deskriptif dengan pendekatan kualitatif. Metode penelitian dengan wawancara mendalam, FGD, dan observasi. Sumber informasi dalam penelitian ini berjumlah tujuh orang ditambah dengan dua orang informan ahli. Berdasarkan hasil penelitian, rancangan dan tanggap darurat terhadap bahaya kebakaran di Rumah Sakit Bhakti Dharma husada masih memerlukan banyak perbaikan. Belum dibentuknya regu khusus penanggulangan kebakaran, sarana penanggulangan kebakaran yang tersedia hanya APAR, dan jumlah serta pemasangan APAR yang ada juga tidak sesuai standar yang berlaku, frekuensi pelatihan dan simulasi penanggulangan kebakaran jarang dilakukan. Saran penelitian adalah segera dibentuk regu khusus penanggulangan kebakaran. dilakukan juga sosialisasi mengenai prosedur penanggulangan kebakaran kepada seluruh karyawan dan pengunjung rumah sakit. Untuk sarana dan prasarana yang ada, terutama APAR perlu diperbaiki dalam pemasangan agar disesuaikan dengan peraturan yang ada. Pelatihan dan simulasi penanggulangan kebakaran juga harus lebih sering dilakukan, terutama kepada karyawan baru.
\end{abstract}

Kata kunci: Rancangan dan Tanggap Darurat, Penanggulangan Kebakaran, Rumah Sakit

\section{PENDAHULUAN}

Kesehatan dan keselamatan kerja dirumah sakit sampai saat ini belum menjadi prioritas penting bagi pihak rumah sakit. Rumah sakit masih lebih mementingkan kelangsungan usaha, keuntungan, pemenuhan kebutuhan logistic, sumber daya manusia dan pengembangan jenis pelayanan baru. Sementara itu karyawan rumah sakit, terutama mereka yang beresiko tinggi mengalami penyakit akibat kerja atau kecelakaan kerja seperti dokter, perawat, radiolog, petugas laboratorium dll belum mendapatkan perhatian yang cukup. Adanya identifikasi bahaya sangat penting untuk mengurangi adanya kejadian yang tidak diinginkan. Kasus kebakaran yang pernah melanda Kozlovichi Mental Asylum (Rumah Sakit Jiwa Kozlovichi) di Provinsi Grodno, Belarus pada Oktober 2003 mengakibatkan 30 pasiennya meninggal dunia. Kejadian di Indonesia pernah melanda Rumah Sakit Jiwa Grogol, Jakarta Barat pada November 2008. Kejadian kebakaran tersebut membuat panik sekitar 30 petugas yang harus mengevakuasi sekitar 160 pasien gangguan jiwa. Rumah sakit merupakan salah satu tempat yang juga tidak lepas dari berbagai kemungkinan bahaya kecelakaan ataupun kebakaran, oleh karena itu perlu juga dibuat suatu sistem rancangan dan tanggap darurat terhadap bahaya kebakaran yang baik, melakukan identifikasi dan menyediakan peralatan tanggap darurat yang sesuai, serta melakukan uji coba secara periodik 


\section{KERANGKA KONSEPTUAL PENELITIAN}

Keadaan darurat adalah situasi atau kondisi yang tidak normal yang sifatnya terjadi tiba tiba. Keadaan darurat dapat berubah menjadi bencana yang mengakibatkan banyak korban, Kerugian atau kerusakan apabila tidak dilakukan penanganan secar tepat dan tepat. Salah satu kondisi yang menggambarkan keadaan tersebut adalah kebakaran ( Budiarto 2006).

Kebakaran adalah sesuatu hal yang tidak di inginkan ,karena dapat menimbulkan.Penderitaan dan malapetaka. Api terjadi akibat tiga unsur pembentuk api yaitu bahan bakar, panas dan oksigen yang dinamakan segitiga api,satu unsur lagi yang cukup penting dalam proses pembakaran adalah reaksi rantai.Reaksi rantai menunjukan suatu proses pembakaran yang berkesinambungan. Ketiga unsur tersebut akan dapat digambarkan bidang empat api (Tanubrata dan Pranata 2006).

Rumah sakit merupakan salah satu tempat yang juga tidak lepas dari berbagai kemungkinan bahaya kecelakaan ataupun kebakaran, oleh karena itu perlu juga dibuat suatu sistem rancangan dan tanggap darurat terhadap bahaya kebakaran yang baik, melakukan identifikasi dan menyediakan peralatan tanggap darurat yang sesuai, serta melakukan uji coba secara periodic

\section{Rumah Sakit $\rightarrow$ Rancangan dan Tanggap Darurat $\rightarrow$ Kebakaran}

\section{METODOLOGI PENELITIAN}

Penelitian ini adalah penelitian deskriptif dengan pendekatan kualitatif. Metode penelitian dengan wawancara mendalam, FGD, dan observasi. Sumber informasi dalam penelitian ini berjumlah tujuh orang ditambah dengan dua orang informan ahli.

\section{TAHAP PENELITIAN}

Populasi yang ada dirumah sakit $\downarrow$

Pengambilan data yaitu wawancara
Pengambilam data diakhir dengan FGD

$\downarrow$

Analisa data $\downarrow$

Kesimpulan

\section{HASIL DAN ANALISA DATA}

Rumah Sakit Umum Daerah Bhakti Dharma Husada terletak di Jalan Raya Kendung No.115 - 117, Kelurahan Sememi, Kecamatan Benowo, Surabaya. Nomor telepon (031) 7409135. Luas tanah RSUD ini adalah 25.690,30 m dan luas bangunan15.733,53 m.

Berdasarkan jenis pelayanan yang diberikan, Rumah Sakit Umum Daerah Bhakti Dharma Husada dikategorikan dalam Rumah Sakit Umum, yaitu Rumah Sakit yang memberikan pelayanan kesehatan pada semua bidang dan jenis penyakit.

Rumah Sakit Bhakti Dharma Husada berkapasitas 229 tempat tidur. Sesuai dengan Standar Penyelenggaraan Rumah Sakit Kelas B, C dan D Direktorat Pelayanan Medik dan Gigi Spesialistik, Direktorat Jenderal Bina Pelayanan Medik, Departemen Kesehatan RI Tahun 2005, maka Rumah Sakit Bhakti Dharma Husada masuk dalam klasifikasi Kelas C yaitu Rumah Sakit yang mempunyai minimal 100 tempat tidur untuk perawatan.

Tabel 1 Perincian Ruang dan Jumlah Tempat Tidur

\begin{tabular}{|l|c|}
\hline Perincian Ruang & $\begin{array}{l}\text { Jumlah Tempat } \\
\text { Tidur }\end{array}$ \\
\hline Kelas Utama (Ruang Krisna) & 10 \\
\hline Kelas I (Ruang Yudhistira) & 10 \\
\hline $\begin{array}{l}\text { Kelas II (Ruang Bima dan } \\
\text { Arjuna) }\end{array}$ & 12 \\
\hline $\begin{array}{l}\text { Paliatif } \\
* \text { Kelas I }\end{array}$ & 1 \\
$*$ Kelas II & 3 \\
\hline
\end{tabular}




\begin{tabular}{|c|c|}
\hline$*$ Kelas III & 3 \\
\hline Kelas III A (Ruang Nakula) & 24 \\
\hline Kelas III B (Ruang Sadewa) & 25 \\
\hline Pediatric (Ruang Ganesha) & 2 \\
$* \quad$ Kelas I & Kelas II \\
$* \quad$ Kelas III & 10 \\
\hline Bersalin (Ruang Srikandi) & Kelas I \\
$* \quad$ Kelas II & 2 \\
$* \quad$ Kelas III & 2 \\
\hline Intensive Care Unit (ICU) & 11 \\
\hline Instalasi Gawat Darurat (IGD) & 10 \\
\hline Jumlah Total Tempat Tidur & 135 \\
\hline
\end{tabular}

Jenis Pelayanan yang Dimiliki Oleh Rumah Sakit Bhakti Dharma Husada

a. Pelayanan Medik Dasar

1) . Pelayanan Medik Umum

2). Pelayanan Medik Gigi Dasar

3). Pelayanan KIA / KB

b. Pelayanan Gawat Darurat

c. Pelayanan Spesialis Dasar

1) . Pelayanan Penyakit Dalam

2). Pelayanan Spesialis Bedah

3) . Pelayanan Spesialis Obstetri dan Ginekologi

4) . Pelayanan Spesialis Anak

d. Pelayanan Spesialis Penunjang

1). Pelayanan Anestesiologi

2) . Pelayanan Radiologi

3) . Pelayanan Patologi Klinik

e. Pelayanan Spesialistik Lain

1) . Pelayanan Spesialis Mata

2) . Pelayanan Spesialis THT

3). Pelayanan Spesialis Penyakit Kulit dan Kelamin

4) . Pelayanan Spesialis Penyakit Syaraf

5). Pelayanan Spesialis Jantung

6) . Pelayanan Spesialis Bedah Orthopedi dan Traumatologi

7) . Pelayanan Spesialis Bedah Plastik

8) . Pelayanan Spesialis Kesehatan Jiwa

f. Pelayanan Spesialistik Gigi Mulut

1). Pelayanan Spesialis Konservasi Gigi / Endodonsi

2) . Pelayanan Spesialis Kesehatan Gigi Anak / Pedodonsi

g. Pelayanan Penunjang Medik

1). Pelayanan Intensif

2) . Pelayanan IBS / OK

3). Pelayanan Darah

4). Pelayanan Gizi

5) . Pelayanan Farmasi

6) . Pelayanan Sterilisasi Instrumen

7) . Rekam Medik

8) . Pelayanan Fisioterapi

9) . Pelayanan VCT

10) . Pelayanan Paliatif

11) . Pelayanan K3RS

h. Pelayanan penunjang Non Klinik

1) . Laundry / Linen

2) . Pelayanan Jasa Boga / Dapur

3). Pelayanan Tehnik dan Pemeliharaan Fasilitas

4) . Pengelolaan Limbah

5) . Gudang

6) . Transportasi (Ambulance)

7) . Komunikasi

8) . Pemulasaran Jenazah

9) . Pemadam kebakaran

10) . Penampungan Air Bersih

i. Pelayanan Administrasi

1) . Informasi dan Penerimaan Pasien

2). Keuangan

3) . Personalia

4) . Keamanan

5) . Sistem Informasi Rumah Sakit

\section{PEMBAHASAN}


Pelaksanaan Kesehatan dan Keselamatan Kerja (K3) adalah salah satu bentuk upaya untuk menciptakan tempat kerja yang aman, sehat, bebas dari pencemaran lingkungan, sehingga dapat mengurangi dan atau bebas dari kecelakaan kerja dan penyakit akibat kerja yang pada akhirnya dapat meningkatkan efisiensi dan produktivitas kerja. Kecelakaan kerja tidak saja menimbulkan korban jiwa maupun kerugian materi bagi pekerja dan pengusaha, tetapi juga dapat mengganggu proses produksi secara menyeluruh, merusak lingkungan yang pada akhirnya akan berdampak pada masyarakat luas. Penyakit Akibat Kerja (PAK) dan Kecelakaan Kerja (KK) di kalangan petugas kesehatan dan non kesehatan kesehatan di Indonesia belum terekam dengan baik. Jika kita pelajari angka kecelakaan dan penyakit akibat kerja di beberapa negara maju (dari beberapa pengamatan) menunjukan kecenderungan peningkatan prevalensi. Sebagai faktor penyebab, sering terjadi karena kurangnya kesadaran pekerja dan kualitas serta keterampilan pekerja yang kurang memadai. Banyak pekerja yang meremehkan risiko kerja, sehingga tidak menggunakan alat-alat pengaman walaupun sudah tersedia. Dalam penjelasan undang-undang nomor 23 tahun 1992 tentang Kesehatan telah mengamanatkan antara lain, setiap tempat kerja harus melaksanakan upaya kesehatan kerja, agar tidak terjadi gangguan kesehatan pada pekerja, keluarga, masyarakat dan lingkungan disekitarnya.

\section{Bahaya Yang Dihadapi Dalam Rumah Sakit}

Dalam pekerjaan sehari-hari petugas kesehatan selalu dihadapkan pada bahaya-bahaya tertentu, misalnya bahaya infeksius, reagensia yang toksik, peralatan listrik maupun peralatan kesehatan. Secara garis besar bahaya yang dihadapi dalam rumah sakit atau instansi kesehatan dapat digolongkan dalam :

1. Bahaya kebakaran dan ledakan dari zat/bahan yang mudah terbakar atau meledak (obatobatan).

2. Bahan beracun, korosif dan kaustik .

3. Bahaya radiasi

4. Luka bakar .

5. Syok akibat aliran listrik

6. Luka sayat akibat alat gelas yang pecah dan benda tajam .

7. Bahaya infeksi dari kuman, virus atau parasit.
Umumnya bahaya tersebut dapat dihindari dengan usaha-usaha pengamanan, antara lain dengan penjelasan, peraturan serta penerapan disiplin kerja. Pada kesempatan ini akan dikemukakan manajemen keselamatan dan kesehatan kerja di rumah sakit / instansi kesehatan.

Hasil laporan National Safety Council (NSC) tahun 2008 menunjukkan bahwa terjadinya kecelakaan di RS $41 \%$ lebih besar dari pekerja di industri lain. Kasus yang sering terjadi adalah tertusuk jarum, terkilir, sakit pinggang, tergores/terpotong, luka bakar, dan penyakit infeksi dan lain-lain. Sejumlah kasus dilaporkan mendapatkan kompensasi pada pekerja RS, yaitu sprains, strains : 52\%;contussion, crushing, bruising : 11\%; cuts, laceration, punctures: $10.8 \%$; fractures: $5.6 \%$; multiple injuries: $2.1 \%$; thermal burns: $2 \%$; scratches, abrasions: $1.9 \%$; infections: $1.3 \%$; dermatitis: $1.2 \%$; dan lain-lain: $12.4 \%$ (US Department of Laboratorium, Bureau of Laboratorium Statistics, 1983).

\section{Kesehatan dan Keselamatan Kerja sebagai Pilihan Rasional Rumahsakit}

Penelitian Bambang mengukur sembilan aspek yang bisa dijadikan tolok ukur bahwa rumahsakit itu memberikan komitmen pelaksanaan K3RS. Seluruh rumahsakit menyediakan sejumlah dana untuk keperluan K3RS. Seperti terlihat dalam tabel di bawah ini, 6 dari 7 rumahsakit belum memiliki sistem keamanan dan tenaga khusus bidang K3RS. Lima rumahsakit belum memiliki sarana IPAL dan sistem pengawasan yang memadai. Selain itu, observasi di lapangan, rumahsakit-rumahsakit ini tidak memiliki sistem pelaporan tentang kecelakaan maupun penyakit akibat kerja.

\section{Rencana/rancangan dalam menghadapi keadaan darurat kebakaran di Rumah Sakit Bhakti Dharma Husada}

Hasil penelitian Angela (2006) menyatakan bahwa kebakaran dapat terjadi akibat aliran listrik 
hubungan singkat, gesekan rol mesin dan gesekan mekanis mesin sehingga perlu diamati secara ketat

RS Bhakti Dharma Husada belum dibentuk tim atau regu khusus penanggulangan kebakaran. Menurut Ardianus (2009) tim atau regu khusus penanggulangan kebakaran di suatu tempat kerja perlu dibentuk, dan sebagai ujung tombaknya adalah satpam yang juga perlu dibekali dengan pelatihan mengenai penanggulangan kebakaran. Selain itu hal tersebut juga sudah diatur dalam ketentuan perundangan yaitu Keputusan Menteri Tenaga Kerja RI No.186 Tahun 1999 mengenai pembentukan Unit Penanggulangan Kebakaran. Rencana/rancangan menghadapi keadaan darurat dimaksudkan untuk mempersiapkan koordinasi dan petunjuk bagi rencana kegiatan organisasi/perusahaan, kesiagaan untuk bertindak dan mendeteksi kejanggalan pada kegiatan organisasi (pada proses pelayanan) dan/atau gejala alam, dimana diduga kemungkinan akan adanya kecelakaan baik perseorangan, gangguan di wilayah kerja atau kekacauan lingkungan. Penyusunan rencana/rancangan tersebut diatas, mengacu pada informasi sebagai berikut a.Kemungkinan akan bahaya.

b. System peringatan bahaya.

c. Prosedur pengaturan tugas \& bertindak.

d. Manajemen dan control

e. Komunikasi di lapangan.

f. Urutan Kuasa.

g. Tindakan / kegiatan anggota

h. Pusat organisasi keadaan darurat

i. Prosedur pemindahan ( evakuasi )

j. Kelompok penolong

k. Modal.

Tanda dan peringatan yang baik dan benar untuk menghadapi keadaan darurat dapat dibuat sesuai dengan kebutuhan masing-masing, seperti :

a)Deteksi kebakaran

b)Alarm kebakaran

c)System peralatan deteksi

d)Teriakan para pekerja.

e)Peringatan dari luar.

Rencana/rancangan tersebut harus berisikan informasi yang memungkinkan siapa saja untuk bisa menguasai keadaan darurat, seperti membunyikan alarm dan memberitahukan kepada atasan mereka secepatnya.

\section{Pendidikan dan latihan penanggulangan kebakaran di Rumah Sakit Bhakti Dharma Husada Surabaya}

Pihak rumah sakit belum pernah mengadakan pelatihan penanggulangan kebakaran, khususnya cara penggunaan APAR. Namun, apalagi terhadap karyawan-karyawan baru.

Menurut Ardianus (2009), menyatakan bahwa pendidikan dan latihan dalam penanggulangan kebakaran itu penting sekali dilakukan. Mengingat saat terjadinya kebakaran bisanya timbul kepanikan. Pelatihan dasar yang paling penting adalah tata cara penggunaan APAR. Pendidikan dan latihan dalam menghadapi keadaan darurat, dimaksudkan selain untuk memastikan perlindungan yang maksimal bagi jiwa dan kekayaan ( gedung, mesin/peralatan, kendaraan dan lain-lain), juga untuk mengurangi timbulnya situasi dengan akibat yang merugikan. Persyaratan utama yang harus dimengerti oleh para pekerja adalah mengerti dan memahami kegunaan dari : prosedur tanggap darurat dan rencana/rancangan dalam menghadapi keadaan darurat serta memahami segala sesuatu yang berhubungan dengan prosedur penanggulangannya.

\section{Penanggulangan keadaan darurat kebakaran di Rumah Sakit Bhakti Dharma Husada}

Rumah Sakit belum memiliki prosedur penanggulangan keadaan darurat kebakaran, meliputi uraian tugas, tindakan yang perlu diperhatikan pada waktu terjadinya kebakaran, kemudian juga metode evakuasi dan pengamanan. Prosedur tersebut memang sudah dibuat dengan baik, namun untuk di setiap ruangan belum memiliki petunjuk teknis penanggulangan keadaan darurat kebakaran, termasuk juga nomor telepon darurat.

Sarana dan prasarana yang tersedia di Rumah Sakit BDH.dalam menghadapi kebakaran adalah APAR. Sarana dan prasarana lain seperti hydrant, sprinkler, dan alarm kebakaran sudah dimiliki. 
Pemeliharaan terhadap sarana berupa APAR ini dilakukan setiap satu tahun sekali. Untuk pemasangan dan tata letak APAR di Rumah Sakit BDH ini juga kurang sesuai dengan Peraturan Menteri Tenaga Kerja dan Transmigrasi Nomor 4 Tahun 1980. Karena dari hasil observasi ada beberapa tabung berkarat dan label petunjuk pemakaian rusak

Menangani/menangulangi keadaan darurat, khususnya dilingkungan rumah sakit diperlukan usaha bersama dari seluruh tim penyelamat ( Rescue Team). Untuk itu kelompok-kelompok tim penanggulangan keadaan darurat ( Emergency Response Team) harus sudah dibentuk dengan nama khusus, tindakan-tindakan dan kepada siapa harus dilaporkan dan koordinasi apa yang ada. Berikut ini adalah kelompok penanggulangan keadaan darurat yang bisa dibentuk: a.Pusat Koordinator selaku Pos Komando.

b.Tim Penyelamat yang berpengalaman di bidang Pertolongan Pertama.

c.Tim/Regu Pemadam Kebakaran.

d.Keamanan ( Satuan Pengamanan/SATPAM).

e.Anggota staff lain yang terpilih

\section{KESIMPULAN}

1. Rumah sakit BDH telah menetapkan komitmen dan kebijakan keselamatan dan kesehatan kerja. Tetapi untuk komitmen dan kebijakan dalam upaya rancangan dan tanggap darurat kebakaran masih perlu mendapat perhatian.

2. Dari aspek rencana atau rancangan dalam menghadapi kebakaran, belum terbentuknya regu khusus penanggulangan kebakaran dan masih banyak sekali pelanggaran terhadap peraturan yang dibuat, terutama larangan merokok di area rumah sakit.

3. Dari aspek pendidikan dan latihan penanggulangan kebakaran belum pernah dilakukan.

4. RS BDH belum memiliki prosedur tertulis seandainya terjadi kasus kebakaran dan upaya sosialisasi untuk prosedur kebakaran tersebut masih kurang. Dilihat dari aspek sarana dan prasarana yang dipersiapkan dalam penanggulangan keadaan darurat, saat ini adalah APAR. Namun jumlah APAR tersebut masih kurang, pemasangannya tidak dilengkapi dengan tanda pemasangan yang jelas. Dan untuk pemeriksaan APAR Sebaiknya dilakukan satu tahun sekali.

5. RS BDH sudah memiliki petunjuk evakuasi yang harus dilakukan saat terjadi kebakaran yang termasuk dalam prosedur penanggulangan kebakaran. Namun untuk petunjuk dimana titik kumpul (assembly point) belum ada.

\section{SARAN}

1. Disarankan segera di buat protap atau kebijakan dari direktur mengenai tim penanggulangan kebakaran

2. Untuk terlaksananya suatu rancangan dan tanggap darurat yang baik, disarankan agar segera dibentuk tim atau regu khusus penanggulangan kebakaran.

3. Perhatian terhadap upaya pencegahan bahaya kebakaran perlu ditingkatkan lagi misalkan: Larangan tegas merokok di area rumah sakit

4. Disarankan agar pendidikan dan pelatihan terhadap upaya penanggulangan kebakaran agar lebih sering dilakukan.

5. Kelengkapan sarana dan prasarana dalam penanggulangan kebakaran sdh cukup baik. Selain APAR yang juga perlu dilengkapi karena ada ruangan yang belum memiliki APAR, alatalat yang belum ada seperti alarm kebakaran.

6. Persiapan evakuasi seandainya terjadi kebakaran disarankan untuk segera dilengkapi,seperti tangga darurat, pintu darurat dan titik kumpul (assembly point). Selain itu juga simulasi terjadinya kebakaran juga perlu dilakukan secara berkala.

\section{DAFTAR PUSTAKA}

Admin, (2008). Polusi Udara. Nasri, Sjahrul M. 2000, 'Risiko tinggi di tempat kerja rumah sakit', in Kumpulan Makalah Seminar K3 RS Persahabatan Tahun 2000 \& 2004. UI-Press, Jakarta, pp. 119-133.

Wikipedia, 2006, 'Kozlovichi Mental Asylum'. [online], Dari: www.en.wikipiedia.org. [11 Juni 2009].

Ferdianto, Riky. 2008, 'RS Jiwa Grogol Terbakar, 160 Pasien Panik'. [online], Dari: www.tempointeractive.com. [25 Mei 2009]. 
Suardi, Rudi. 2005, Sistem Manajemen Keselamatan dan Kesehatan Kerja Panduan Penerapan Berdasarkan OHSAS 18001 dan Permenaker 05/1996. Penerbit PPM, Jakarta.

Budiono, A.M. Sugeng., R.M.S Jusuf \& Adriana Pusparini. 2008, Bunga Rampai Hiperkes \& KK. Badan Penerbit Universitas Diponegoro, Semarang.

Angela, Theresia Audrey. 2006, 'Studi Kasus: Evaluasi Sistem Penanggulangan Kebakaran PT. Indogravure', Jurnal Kesehatan Masyarakat Nasional, vol.1, no.2, Oktober., pp 6368.Elsevier Ltd. Oxford.

Keputusan Mentri Pekerjaan Umum Nomor : 10/Kpts/2000 Tentang Ketentuan Teknis Pengamanan Terhadap Bahaya Kebakaran Pada Bangunan Gedung Dan Lingkungan

Iftitah, S.M., 2010. Tinjauan sarana proteksi aktif dan sarana penyelamatan jiwa dalam penanggulangan kebakaran di gedung baru rumah sakit TNI Angkatan Laut Dr. Mintohardjo. Skripsi. Universitas Pembangunan Nasional. Jakarta.

Laila, K.N., 2009. Perancangan Sarana Evakuasi dan Evaluasi Apar Pada PT. Pakarti Riken Indonesia. Tugas Akhir. Politeknik Perkapalan Negeri Surabaya. Surabaya.

NFPA 101 Tahun 2000 tentang Life Safety Code.

NFPA 1600 Tahun 2000 tentang Standard on Disaster/Emergency Management and Business Continuity Programs.

Notoadmodjo, S., 2005. Metodologi Penelitian Kesehatan. Rineka Cipta. Jakarta

Pragola, R.H.K., 2008. Evaluasi Sarana Pencegahan dan Penanggulangan Kebakaran di Gedung OSI PT. Krakatau Steel. Skripsi. FKM UI. Jakarta
Rachmawati, R.R., 2009. Penilaian Program Emergency Response Preparedness PT. McDermott Indonesia Fabrikasi Batam. Skripsi. FKM UI. Jakarta

Ramli, S., 2010. Manajemen Tanggap Darurat. Dian Rakyat. Jakarta

Ramli, S., 2010. Manajemen Kebakaran. Dian Rakyat. Jakarta

Sahab, S., 1997. Teknik Manajemen Kesehatan dan Keselamatan Kerja. PT. Bina Sumber Daya Manusia. Jakarta

Septiadi, F., 2008. Menganalisa persiapan menghadapi tanggap darurat di Gedung Pusat Telokomunikasi Telepon Seluler (PT. SIEMENS-INDONESIA) berdasarkan standar ISRS. Skripsi. Jakarta. Universitas Indonesia

SNI 03-1746-2000 tentang Tata Cara Perencanaan dan Pemasangan Sarana Jalan Keluar untuk Penyelamatan terhadap Bahaya Kebakaran pada Bangunan Gedung.

Sumardjito, 2010. Kajian Terahadap Sarana Emergency Exit pada Bangunan Pusat Perbelanjaan di Yogyakarta. Laporan Penelitian. Universitas Negri Yogyakarta

Undang-Undang Republik Indonesia Nomor 24 Tahun 2007 Tentang Penanggulangan Bencana

Walton, W.D., 2002. SFPE Handbook of Fire Protection Engineering. National Fire Protection Association, Inc. Massachusetts

Yung, D., 2008. Principles of Fire Risk Assessment in Buildings. Yung \& Associates Inc., Toronto, Canada 